\title{
Genetic inventory of European oak populations: consequences for breeding and gene conservation
}

\author{
S Herzog \\ Abteilung für Forstgenetik und Forstpflanzenzüchtung, Georg-August-Universität, \\ Büsgenweg 2, 37077 Göttingen, Germany
}

(Received 6 September 1994; accepted 18 July 1995)

\begin{abstract}
Summary - The objective of the present study was to characterize the genetic variation in pedunculate oak and sessile oak populations on the basis of isoenzyme markers and to perform a genetic inventory of European oak populations. The results are discussed with special respect to forest tree breeding and conservation of genetic resources. Previous results on oak genetics, summarized in the present paper, are also discussed. The results reveal a relatively high genetic variation among individuals in terms of actual heterozygosities, compared to other plant species. In addition, intrapopulational variation is large. Genetic differentiation among populations of each species is relatively small in general, with certain exceptions. In contrast to earlier results, which suggest smaller differentiation values for pendunculate oak as compared to sessile oak, the present results indicate an opposite trend. The results presented herein suggest that forest tree breeding and silviculture of sessile and pedunculate oak need to take into account large genetic multiplicities. It seems improbable that we can find single stands representing the whole or nearly the whole genetic variation of the species. This would call for a management which is focused on the in situ maintenance of numerous and sufficiently large, locally adapted stands.
\end{abstract}

oak / isoenzyme / genetic variation / gene conservation / breeding

Résumé - Inventaire génétique de populations de chênes européens : conséquences pour la sélection et la conservation de la diversité. L'objectif de la présente étude était de caractériser la variabilité génétique des chênes sessiles et pédonculés sur la base d'une étude de marqueurs isoenzymatiques, et de réaliser un inventaire génétique de populations européennes de ces chênes. Les résultats sont discutés plus particulièrement du point de vue de leurs implications pour les stratégies de sélection et de conservation des ressources génétiques. Des résultats antérieurs sont également résumés et discutés dans cet article. Nos mesures ont révélé qu'en comparaison avec d'autres espèces les chênes présentent une relativement forte variabilité génétique entre individus en termes d'hétérozygotie. La différenciation génétique entre populations de chaque espèce est généralement assez faible, à quelques exceptions près. Nous avons observé que, contrairement à ce qui avait été suggéré antérieurement, un degré de différenciation plus important apparaissait dans l'espèce "pédonculé" que 
dans l'espèce "sessile". Cette importante variabilité génétique devra être prise en compte pour la sélection et la sylviculture de ces chênes. II paraît peu probable que nous puissions trouver des peuplements présentant même partiellement l'ensemble de la variabilité génétique de chacune des espèces. Cela devrait mener à une gestion permettant de maintenir en place des peuplements nombreux et suffisamment étendus, adaptés aux conditions locales.

\section{chêne / isoenzyme / variabilité génétique / amélioration génétique / biodiversité}

\section{INTRODUCTION}

Oaks form one of the major deciduous tree species in Europe. Two species, ie, Quercus robur (pedunculate oak) and $Q$ petraea (sessile oak) are quantitatively predominating in Central Europe. They are carrier species of complex, economically as well as ecologically, important forest ecosystems and range from the flood plains along the rivers to the montane regions. Oaks are long-lived species with forest rotation cycles of 200 and more years. Thus, they are exposed to more heterogeneous environmental conditions than most other predominant tree species.

Genetic resources of oaks are endangered not only by the loss of natural ecosystems such as the natural fertile plains but also by the impact of air pollution for several decades and may be even by long-term climate changes (see for example, Herzog, 1988b; Ziehe et al, 1989). Moreover, silvicultural customs, especially the limitation of seed sources, may also contribute to the loss of genetic ressources. In addition, for several years we have been able to observe an increasing impact of air pollutant even on broad-leaved trees such as oaks and beech.

The conservation of genetic resources in oaks requires particular concepts, dependent primarily on the genetic structures of the populations in question. Information on the patterns of genetic variation will lead to a better understanding of principles of adaptation and survival of long-lived tree species. Such data are needed to develop criteria for the choice of reproductive material, for silvicultural treatment as well as for the development of a concept for conservation of genetic ressources.

\section{MATERIALS AND METHODS}

The present study is based on the investigation of 12 sessile oak ( $Q$ petraea Liebl) populations from Great Britain, France, Denmark and Germany as well as nine pedunculate oak ( $Q$ robur $L$ ) populations from Scotland, the Netherlands and Germany (fig 1). In addition, the results of preliminary studies of Müller-Starch and Ziehe (1991), Kremer et al (1991), Müller-Starck et al (1993), Herzog and Müller-Starck (1993) on seed or juvenile populations as well as the first results of an unpublished study of Herzog and Krabel on adult populations are discussed in the context of the present study.

The samples represent locally adapted but not necessarly autochthoneous populations of sessile and pedunculate oak. The sample size was 1002 -year-old trees per population, randomly collected out of the seed of 1 year and grown under homogeneous conditions. This means a probability of $95 \%$ to detect alleles with a frequency of at least $\alpha=5.99$.

Buds or young leaves were sampled and immediately frozen in liquid nitrogen before storage at $-80^{\circ} \mathrm{C}$. They were thawed and homogenized in a $0.08 / 0.02 \mathrm{~mol} / \mathrm{L}$ Tris $\mathrm{HCl}$ buffer at $\mathrm{pH}$ 7.3. To inhibit phenols and tannins, $2-5 \%[\mathrm{w} / \mathrm{v}]$ polyvinylpyrrolidone, $10-130 \mathrm{mmol} / \mathrm{L}$ mercaptoethanol, $3 \mathrm{mmol} / \mathrm{L}$ ethylemediaminetetraacetic acid (EDTA) as well as $3-6 \mathrm{mmol} / \mathrm{L}$ dithiothreitol were added. The resulting slurry was absorbed onto filter paper wicks and loaded onto gel slabs. Horizontal starch gel electrophoresis was performed using a starch concentration of $11.5 \%$ $(\mathrm{w} / \mathrm{v})$. The bridge distance was $12 \mathrm{~cm}$ with a voltage distribution of $20-30 \mathrm{~V} / \mathrm{cm}$. 


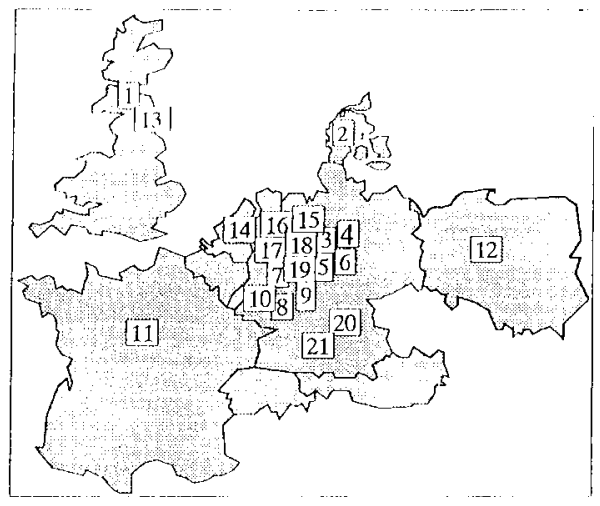

Fig 1. Schematic map of parts of Europe and the populations studied (for identification of the single populations see table II).
Ten izoenzyme systems (table I) representing 14 polymorphic gene loci, were identified as genetic markers. They were studied using different electrode and gel buffer systems (table I). Solutions used for enzyme staining were modified following Cheliak and Pitel (1984).

The interpretation of the results is based on the measure of genetic distance as well as the concepts of variation within and differentiation between populations, as extensively described by Gregorius $(1974,1984,1987)$ or Gregorius and Roberds (1986) and critically discussed by Herzog (1988a).

\section{RESULTS}

The results of the present study are summarized in the tables II-V and figures 2-5.

Table I. Enzyme systems and buffers used in the present study.

Enzyme system and EC code

Shikimate dehydrogenase EC 1.1.1.25

Malate dehydrogenase EC 1.1.1.37

Isocitrate dehydrogenase EC 1.1.1.42

6-Phosphogluconate dehydrogenase EC 1.1.1.44

Glutamate dehydrogenase

EC 1.4.1.2

Menadione reductase EC 1.6.99.2

Glutamate-oxalacetate transaminase EC 2.6.1.1

Phosphoglucomutase EC 2.7.5.1

Aminopeptidases EC 3.4.11.1

Phosphoglucose isomerase EC 5.3.1.9
Electrode buffer and gel buffer

Gene loci

Tris/citric acid, $\mathrm{pH} 7.0$

Tris/histidine, $\mathrm{pH} 5.7$

Tris/citric acid, $\mathrm{pH} 7.0$

Tris/histidine, $\mathrm{pH} 5.7$

Tris/citric acid, $\mathrm{pH} 7.0$

Tris/histidine, $\mathrm{pH} 5.7$

Tris/citric acid, $\mathrm{pH} 7.0$

Tris/histidine, $\mathrm{pH} 5.7$

Boric acid/ $\mathrm{NaOH}, \mathrm{pH} 8.0$ Tris $/ \mathrm{HCl}, \mathrm{pH} 8.5$

Tris/citric acid, $\mathrm{pH} 7.0$

Tris/histidine, $\mathrm{pH} 5.7$

Boric acid/NaOH, pH 8.0 Tris/ $\mathrm{HCl}, \mathrm{pH} 8.5$

Tris/citric acid, $\mathrm{pH} 7.0$

Tris/histidine, $\mathrm{pH} 5.7$

Boric acid/ LiOH, pH $8.1 \quad L A P$

Tris/citric acid, $\mathrm{pH} 8.1$

Boric acid/LiOH, pH 8.1

Tris/citric acid, $\mathrm{pH} 8.1$
GOT-B

GOT-C

$A A P$

SKDH-A

$M D H-A$

$M D H-B$

IDH-A

6-PGD-A

6-PGD-B

$G D H-A$

MNR-A

PGM-A

PHI-A 
Table II. Genetic parameters for 12 sessile oak (Quercus petraea) as well as nine pedunculate oak (Quercus robur) populations: gene pool diversity ( $v$, Gregorius 1978,1987$)$, population differentiation $\left(\delta_{T^{*}}\right.$, Gregorius 1987), and subpopulation differentiation ( $D_{\mathrm{j}}$, Gregorius und Roberds, 1986).

\begin{tabular}{lccc} 
Provenance & $v$ & $\delta_{T^{*}}$ & $\mathrm{D}_{j}$ \\
\hline & & & \\
1. Dymock & 1.305 & 0.235 & 0.059 \\
2. Horbylunde & 1.443 & 0.309 & 0.108 \\
3. Lüß & 1.308 & 0.237 & 0.059 \\
4. Göhrde & 1.358 & 0.256 & 0.051 \\
5. Seelzerthurm & 1.338 & 0.245 & 0.055 \\
6. Lappwald & 1.345 & 0.258 & 0.043 \\
7. Kottenforst & 1.312 & 0.239 & 0.088 \\
8. Bad Münstereifel & 1.374 & 0.274 & 0.085 \\
9. Wolfgang & 1.368 & 0.271 & 0.058 \\
10. Johanniskreuz & 1.321 & 0.244 & 0.056 \\
11. V Saint Hillaire & 1.343 & 0.257 & 0.051 \\
12. Sycow & 1.280 & 0.220 & 0.091 \\
13. Sutton Bottom & 1.290 & 0.226 & 0.126 \\
14. Heesch & 1.246 & 0.198 & 0.127 \\
15. Osterh-Scharmbeck & 1.354 & 0.263 & 0.081 \\
16. Bentheim & 1.351 & 0.261 & 0.065 \\
17. Ville & 1.332 & 0.251 & 0.070 \\
18. Winnefeld & 1.358 & 0.265 & 0.063 \\
19. Radolfshausen & 1.333 & 0.251 & 0.073 \\
20. Farchau & 1.371 & 0.272 & 0.116 \\
21. Ebrach & 1.333 & 0.251 & 0.070 \\
& & & \\
\hline
\end{tabular}

Table III. Pairwise genetic (gene pool) distances $d_{0}$ between populations of sessile oak (Quercus petraea).

$\begin{array}{lcccccccccccc} & 1 & 2 & 3 & 4 & 5 & 6 & 7 & 8 & 9 & 10 & 11 & 12 \\ & & & & & & & & & & & & \\ & & & & & & & & & & & \\ 1 & - & & & & & & & & & & \\ 2 & 0.123 & - & & & & & & & & & \\ 3 & 0.071 & 0.117 & - & & & & & & & & \\ 4 & 0.082 & 0.125 & 0.062 & - & & & & & & & \\ 5 & 0.073 & 0.132 & 0.065 & 0.060 & - & & & & & & \\ 6 & 0.067 & 0.121 & 0.054 & 0.047 & 0.042 & - & & & & & \\ 7 & 0.101 & 0.154 & 0.109 & 0.085 & 0.090 & 0.084 & - & & & & \\ 8 & 0.078 & 0.116 & 0.072 & 0.102 & 0.097 & 0.092 & 0.141 & - & & & & \\ 9 & 0.079 & 0.112 & 0.052 & 0.064 & 0.068 & 0.058 & 0.111 & 0.072 & - & & & \\ 10 & 0.058 & 0.128 & 0.062 & 0.068 & 0.066 & 0.060 & 0.098 & 0.093 & 0.072 & - & & \\ 11 & 0.063 & 0.102 & 0.071 & 0.076 & 0.074 & 0.064 & 0.092 & 0.097 & 0.072 & 0.067 & - & \\ 12 & 0.098 & 0.152 & 0.111 & 0.103 & 0.092 & 0.083 & 0.065 & 0.140 & 0.107 & 0.093 & 0.084 & -\end{array}$

The numbers refer to table II. 
Table IV. Pairwise genetic (gene pool) distances $d_{0}$ between populations of pedunculate oak ( $Q$ robur).

\begin{tabular}{lccccccccc}
\hline & 13 & 14 & 15 & 16 & 17 & 18 & 19 & 20 & 21 \\
\hline 13 & - & & & & & & & \\
14 & 0.088 & - & & & & & & \\
15 & 0.088 & 0.071 & - & & & & & \\
16 & 0.114 & 0.079 & 0.039 & - & & & & \\
17 & 0.114 & 0.075 & 0.042 & 0.053 & - & & & \\
18 & 0.098 & 0.054 & 0.053 & 0.045 & 0.041 & - & & \\
19 & 0.108 & 0.081 & 0.061 & 0.056 & 0.054 & 0.061 & - & \\
20 & 0.150 & 0.106 & 0.077 & 0.064 & 0.078 & 0.087 & 0.070 & - & \\
21 & 0.157 & 0.106 & 0.090 & 0.073 & 0.071 & 0.071 & 0.077 & 0.061 & - \\
& & & & & & & & &
\end{tabular}

Table V. Subpopulation differentiation $\delta$ (Gregorius and Roberds, 1986; Gregorius, 1987) and $G_{S T}$ (Nei, 1973): comparison of the studies to date.

Species (author)

$Q$ petraea (this study)

$Q$ petraea (Zanetto et al, 1994)

$Q$ petraea (Herzog, 1993)

$Q$ petraea (Herzog and Müller-Starck, 1993)

$Q$ petraea (Müller-Starck and Ziehe, 1991)

$Q$ petraea (Kremer et al, 1991)

$Q$ robur (this study)

$Q$ robur (Herzog and Krabel, unpublished data)

$Q$ robur (Zanetto et al, 1994)

$Q$ robur (Müller-Starck and Ziehe, 1991) $\delta / G_{S T}$

$$
\begin{aligned}
& \delta=0.067 \\
& G_{\mathrm{ST}}=0.032 \\
& \delta=0.061 \\
& \delta=0.061 \\
& \delta=0.085 \\
& G_{\mathrm{ST}}=0.024 \\
& \delta=0.088 \\
& \delta=0.091 \\
& G_{\mathrm{ST}}=0.024 \\
& \delta=0.055
\end{aligned}
$$

Concerning the measures of genetic variation within populations, the present study revealed average (arithmetic mean) actual heterozygosities as shown in figure 2 for $Q$ petraea and $Q$ robur. The highest values have been found for $Q$ petraea, the lowest value for one $Q$ robur population from the Netherlands. Diversity was measured using the gene pool diversity ( $v$, Gregorius, 1978, 1987 ) and the total population differentiation ( $\delta_{\top^{*}}$, Gregorius, 1987 ; table II, figs 3 and 4 ). Whereas the present study revealed a total population differentiation $\delta_{\top}{ }^{*}$ ranging between 0.220 and 0.309 for $Q$ petraea and between 0.198 and 0.272 for $Q$ robur, the gene pool diversity $v$ was found to range between $v=1.280$ and $v=1.443$ for $Q$ petraea and from $v=1.246$ to $v=1.371$ for $Q$ petrea.

Concerning the genetic differentiation between populations, genetic distances $d_{0}$ (Gregorius, 1974, 1984, tables III and IV) as well as the gene pool subpopulation differentiation $D_{\mathrm{j}}$ (see table II and fig 5 ) and $\delta$ (Gregorius and Roberds, 1986; Gregorius, 1987; table V) have been applied. Subpopulation differentiation $D_{\mathrm{j}}$ was found to range between 0.051 (Göhrde and V St Hillaire) and 0.108 (Horbylunde) for $Q$ petraea and between 0.063 (Winnefeld) and 0.127 

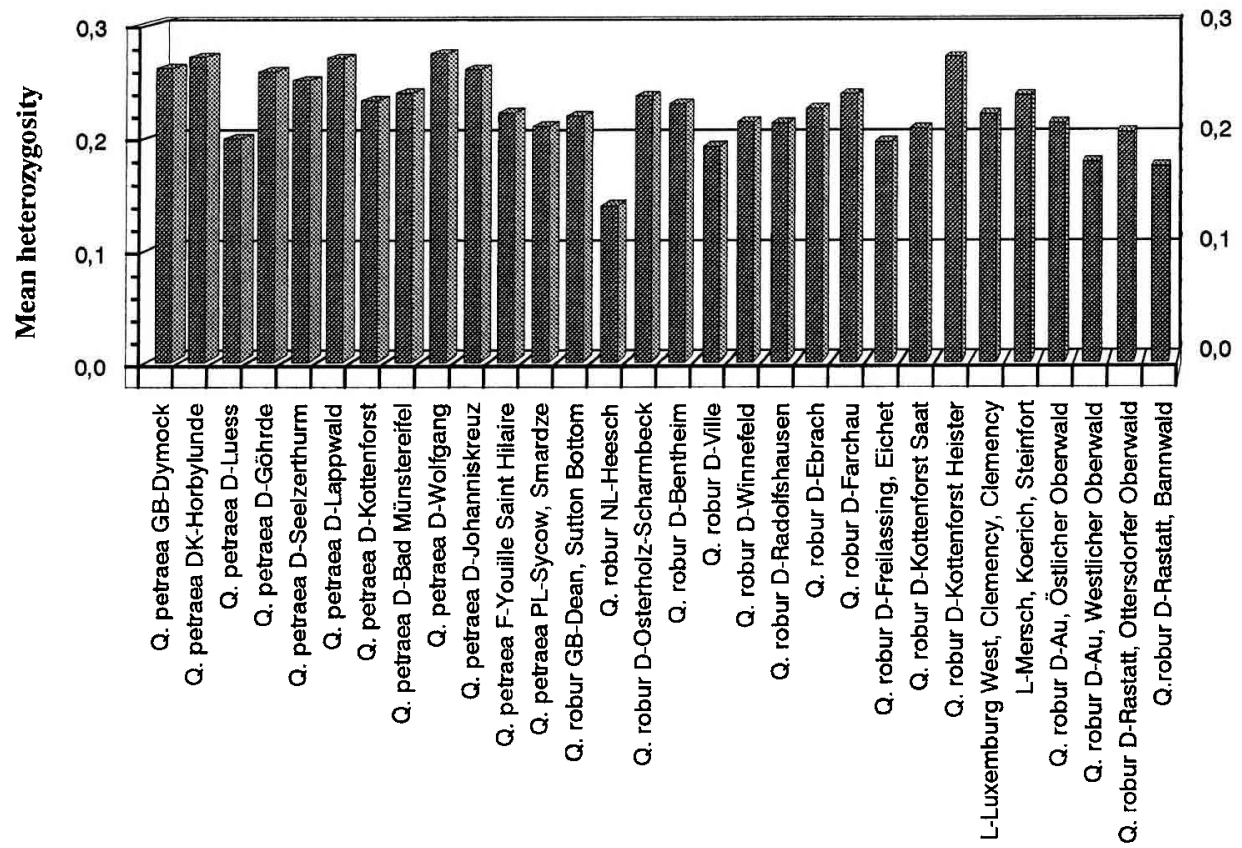

Fig 2. Average heterozygosities of different oak populations, including the populations covered by the present study.

(Heesch) for $Q$ robur. Table $V$ shows the corresponding values for the subpopulation differentiation $\delta$ (Gregorius and Roberds, 1986; Gregorius, 1987) calculated as an average over the above-mentioned $D_{\mathrm{j}} \mathrm{s}$.

\section{DISCUSSION}

\section{Experimental basis}

Nearly all recent results on genetic variation in natural populations are based on electrophoretic studies of protein gene loci. The problems of this approach of estimating genetic structures of a population by electrophoretic analysis of randomly sampled protein gene loci are discussed by Herzog (1988a). One important problem is that electrophoresis reveals only a small fraction of the genomic DNA variation: approximately less than $10 \%$ of the DNA in eukaryotes comprises genes that are transcribed into proteins and only a small proportions of these proteins are electrophoretically detectable by recent methods. Additionally, due to the redundance of the genetic code, about one-third of the base pair substitutions do not influence the amino acid sequence of the respective protein. Another problem is that a sample of protein gene loci depends largely on the biochemical methods, especially the staining procedures that are available and thus it is not a random sample in a strict sense.

However, although molecular biological markers such as restriction fragment length polymorphisms (RFLP) or randomly amplified polymorphic DNAs (RAPD) are quite well established for some biological systems, their use for population genetic pur- 
Fig 3. Allele frequencies at the PGM-A gene locus in a number of sessile oak populations ( $Q$ petraea). poses in natural species has been restricted due to methodological uncertainties until today.

The advantages of protein gene markers and the restrictions of molecular markers makes isozymes the most important tool for genetic inventories, if their immanent system restrictions are kept in mind. Thus, the present data are based on biochemical genetic marker systems.

\section{Variation within populations}

One commonly used measure of genetic variation of individuals and populations is the average degree of heterozygosity. Its estimation relies on genotypic rather than on allelic frequencies; the amount of heterozygosity attainable in a population ('actual amount of heterozygosity', $\mathrm{H}_{A}$ ) depends on the actual allele frequencies. The average heterozygosities found by the present study is of roughly comparable magnitude as revealed by previous investigations on oaks: according to MüllerStarck and Ziehe (1991) as well as MüllerStarck et al (1993), the average heterozygosity at the species level was estimated to be $H_{A}=0.213$ for $Q$ robur and 0.219 (Müller-Starck and Ziehe, 1991) and 0.229 (Müller-Starck et al, 1993) for $Q$ petraea. Zanetto et al (1994) found aver- 
age actual heterozygosities of 0.184 for $Q$ robur and 0.222 for $Q$ petraea. On the other hand, Herzog and Krabel found a relatively high average of $\mathrm{H}_{A}=0.253$ for two populations of $Q$ robur (data not shown).

Deviations from Hardy-Weinberg proportions were observed at several loci, but in most cases expected genotype frequencies are less than 5, which may erroneously suggest rejection of the hypothesis using the $\chi^{2}$-test.

The calculation of $v$ (Gregorius, 1978, 1987) makes the data comparable to other studies. On the other hand, we have to keep in mind that $v$ is influenced by the sample size, whereas $\delta_{\top}{ }^{*}$ is independent of it. The gene pool diversity $v$ was found to range between $v=1.280$ and $v=1.443$ for $Q$ petraea and from $v=1.246$ to $v=1.371$ for $Q$ robur. Müller-Starck and Ziehe (1991) and Müller-Starck et al (1993) calculated gene pool diversities between $v=1.29$ and $v=1.49$ for $Q$ petraea. For $Q$ robur the respective values were found to range between $v=1.33$ and $v=1.41$ (MüllerStarck and Ziehe, 1991; Müller-Starck et al 1993) and between $v=1.35$ and $v=1.47$ (Herzog and Krabel, unpublished data). Thus, the present data correspond well to previous studies on oak populations, but the values are high compared to the results of studies on other woody perennial species. Hamrick and Godt (1990) reanalyzed more than 600 studies covering a total of 110 woody perennials and found an average "effective number of alleles" of 1.24. On the basis of 15 isoenzyme gene loci, Kremer et al (1991) found the respective values to be 1.48 for $Q$ petraea and 1.50 for $Q$ robur. Zanetto et al (1994) found very similar average effective numbers of alleles for $Q$ robur to be 1.49 and for $Q$ petraea to be 1.47. This measure is comparable to the diversity $v$ (see above). Thus, recent studies generally reveal a high level of diversity in pedunculate as well as sessile oak.

\section{Differentiation between populations}

In the present study, the genetic distances $d_{0}$ (Gregorius, 1974, 1984; tables III and IV) as well as the gene pool subpopulation differentiation $D_{\mathrm{j}}$ (see table II and fig 5 ) and $\delta$ (Gregorius and Roberds, 1986; Gregorius, 1987; table $V$ ) have been applied. Genetic distances $\left(d_{0}\right)$ of, say, 0.1 and more provide evidence for a substantial genetic differentiation (see for example, Herzog and Müller-Starck, 1993). However, the genetic distances are poorly correlated to the geographical distances. This means that we should also not expect a good correlation between genetic differentiation and geographic distance of the sites. To estimate the genetic distance "between both species", $Q$ petraea and $Q$ robur, we have chosen the least differentiated population of each species, ie, the populations representing their lumped remainder relatively well. Thus, we calculated the genetic distance between Lappwald and Winnefeld to be $d_{0}=0.165$. Distances between populations of one and the same morphological species are partly of comparable magnitude.

The subpopulation differentiation $\delta$ (Gregorius and Roberds, 1986; table V) found in the present study is equalling $0.067(Q$ petraea) and 0.088 ( $Q$ robur); the corresponding values were found to be 0.055 in $Q$ robur and 0.085 in $Q$ petraea by MüllerStarch and Ziehe 1991. Herzog and MüllerStarck (1993) and Herzog (1993) found $\delta=$ 0.061 for $Q$ petraea. Another study on $Q$ robur revealed $\delta=0.091$ (Herzog and Krabel, unpublished data).

These results provide evidence that the adult stands of pedunculate oak are more differentiated than the juvenile populations of pedunculate and sessile oak. Moreover, the present data show a reduced $\delta$ for sessile oak compared to the studies of MüllerStarck and Ziehe (1991) as well as MüllerStarck et al (1993). In contrast, the present 
study found pedunculate oak to be more differentiated than the above-mentioned authors. However, this may be at least partially caused by differences in the genetic structures dependent on age or by the restricted number of populations. Herzog and Krabel (unpublished data) included only two populations in their study; Müller-Starck et al (1993) observed five populations. Studies of Kremer et al (1991) found juvenile populations of $Q$ petraea, especially in France, to be significantly less differentiated, ie, $G_{S T}=0.024$ for the polymorphic loci and $G_{S T}=0.017$ for all loci. Similar results have been obtained by Zanetto et al (1994) with $G_{S T}=0.024$ for $Q$ robur and $G_{\mathrm{ST}}=0.032$ for $Q$ petraea. This may be partially caused by methodological differences ( $\delta$ values normally exceed the corresponding $G_{\mathrm{ST}}$ values), but nevertheless it can be concluded that sessile oak in France may be less differentiated than in other parts of Europe studied to date. In general, the genetic differentiation of oak populations is of comparable magnitude as observed for other deciduous tree species (Müller-Starck, 1991).

Another question to be addressed is that of rare alleles. The common differentiation measures normally underestimate the influence of alleles occurring in low frequencies, say, less than $10 \%$. For example, we can consider the $P G M-A$ gene locus (fig 3 ).

One allele ( $P G M-A 4)$ predominates and shows a high frequency of more than $80 \%$ with one exception (Horbylunde). The other rare alleles are heterogeneously distributed, which provides evidence for a locally acting selection against different rare alleles, whereas the common allele may be optimized under the present environmental conditions in general. We have to keep in mind that this differentiation pattern caused by rare alleles does not cogently correspond to that revealed by application of the common differentiation measures.

\section{Consequences for forest tree breeding and conservation of genetic resources}

Genetic variation is an important prerequisite for the ability of forest tree populations to survive spatial and temporal variation of environmental conditions, ie, for the adaptability of the tree populations. Therefore, genetic variation is the basis of any evolutionary development. The long-term survival of a species critically depends on its ability to become adapted to changed environmental conditions. Thus a loss of genetic variability would mean a reduced basis for long-term adaptability of a population. An appropriate conservation strategy should preserve this genetic adaptability. This would imply the perpetual preservation of the genetic information contained in populations, but not necessarily the protection of the individual carriers of this information.

Consequently, provisions on gene conservation require an inventory of genetic variation in as many populations of a species as possible. The results of the studies of the last years are a basis for and should contribute a major part to this inventory.

The results of previous studies reveal an extraordinary large intrapopulational variation, whereas the genetic differentiation among populations of each species is relatively small. However, the present study also revealed quite large amounts of genetic differentiation, especially when the geographic distance is taken into account.

In contrast to earlier results, which suggest smaller values for pedunculate oak as compared to sessile oak, the present results indicate an opposite trend. As can be expected, mixtures of population samples from different locations are less differentiated than samples from single locations.

The gene pools of pendunculate oak and sessile oak are very similar. No speciesspecific alleles have been found so far although allele frequencies can vary 
between species. Consequently, genetic distances often are greater between populations of the two different species as compared to populations within each species.

As mentioned above, oaks are carrier tree species of significant forest ecosystems. Compared to other species, oaks are extremely long-lived and cover a wide range of ecologically different forest sites. The results presented herein suggest that forest tree breeding and silviculture of sessile oak and pedunculate oak need to take into account large genetic multiplicities and, at least partially, clear differentiation even between closely neighbouring populations. These findings are supported by morphological and ecological studies (Kleinschmit, personal communication). Genetic heterogeneity should correspond to the history of the populations and in this context especially the influence of humans, but also to the environmental heterogeneity to which long-lived oak populations are exposed (Müller-Starck et al, 1993). It appears that large genetic variation must be incorporated in productive populations in order to maintain the potential of these populations to adapt to and survive in complex environmental situations.

It seems improbable that we can find single stands representing the whole or nearly the whole genetic variation of the species. This would call for a management focused on the in situ maintenance of numerous and sufficiently large, locally adapted stands. Population sizes determine the amount of genetic variation which can be realized and the probability of having a gene with a given frequency represented in the population.

To prevent genetic erosion as a result of genetic drift, effective population sizes must be kept high and/or gene flow between populations must be guaranteed in order to promote genetic polymorphism. Generally, we can say that the populations should be kept as large as possible, but any endangered or threatened population, irrespective of its size, should be kept alive and, if possible, brought into contact to other populations of the same species. Preliminary rough estimations recommend minimum sizes of oak stands serving for gene conservation purposes of 30 to 50 ha (Herzog and MüllerStarck, 1993). Moreover, any long-term strategy of forest management should included a periodical genetic monitoring by a set of simple genetic marker systems.

The special case of 'interspecific' hybridizations provides us with a good example to compare both the concept of 'conservation of adaptedness' and the concept of 'conservation of adaptability'. From a genetic point of view, two major arguments are of importance: on the one hand, the introgression of a foreign population into a locally adapted one normally means a loss of adaptation to the local environmental conditions. This adaptedness, resulting in local 'ecotypes', can be preserved only by preventing the introgression of other, less-adapted types. On the other hand, we should not overlook the fact that each evolutive development of a species requires not only adaptedness to the present environmental conditions but also genetic adaptability to a wide spectrum of possible future environmental conditions. In this context, hybridization leading to an increase of genetic variability need not be a disadvantage and may even be advantageous for the long-term survival of a natural population.

Finally, the present results provide good evidence that genetic conservation of oaks should be possible by means of a regular silvicultural management, if multiple populations are maintained under a set of different natural environments and selection regimes.

\section{ACKNOWLEDGMENTS}

The author is very grateful to $D$ Krabel, $M$ Ziehe and $E G$ Gregorius for helpful comments on an 
earlier version of the manuscript and for linguistic advice. The technical assistance of A Capelle and C Radler is gratefully acknowledged.

\section{REFERENCES}

Cheliak WM, Pitel JA (1984) Electrophoretic identification of clones in trembling aspen. Can J For Res 14, 740743

Gregorius HR (1974) Genetischer Abstand zwischen Populationen. I. Zur Konzeption der genetischen Abstandsmessung. Silvae Genet 23, 22-27

Gregorius HR (1978) The concept of diversity and its formal relationship to heterozygosity and genetic distance. Math Biosci 41, 253-271

Gregorius HR (1984) A unique genetic distance. Biom J 26, 13-18

Gregorius HR (1987) The relationship between the concepts of genetic diversity and differentiation. Theor App/ Genet 74, 397-401

Gregorius HR, Roberds JH (1986) Measurement of genetical differentiation among subpopulations. Theor App/ Genet 71, 826-834

Hamrick JL, Godt MJ (1990) Allozyme diversity in plant species. In: Plant Population Genetics, Breeding, and Genetic Resources (AHD Brown, MT Clegg, AL Kahler, BS Weir, eds), Sinauer Ass, Sunderland, UK

Herzog S (1988a) Cytogenetische und biochemischgenetische Untersuchungen an Hirschen der Gattung Cervus (Cervidae, Artiodactyla, Mammalia). Göttingen Res Notes For Genet 10, 1-139

Herzog S (1988b) Genetische Vielfalt als Stabilitätsfaktor im Waldökosystem. Jagd+Hege 5, 18

Herzog S (1993) Studies on genetic diversity in European oak populations. Proceedings of the 22 nd
Southern Forest Tree Improvement Conference, 14-17 June 1993, Atlanta, GA, 22-231

Herzog S, Müller-Starck G (1993) Untersuchungen zur genetischen Differenzierung bei Stieleiche (Quercus robur $L$ ) und Traubeneiche (Quercus petraea Liebl): Konsequenzen für die Erhaltung genetischer Ressourcen. Forstarchiv 64, 88-92

Kremer A, Petit R, Zanetto A et al (1991) Nuclear and organelle gene diversity in Quercus robur and $Q$ petraea. In: Genetic Variation in European Populations of Forest Trees (Müller-Starck G, Ziehe M, eds), Sauerländer's Verlag, Frankfurt-am-Main, 125-140

Müller-Starck G (1991) Survey of genetic variation as inferred from enzyme gene markers. In: Genetic Variation in European Populations of Forest Trees (Müller-Starck G, Ziehe M, eds), Sauerländer's Verlag, Frankfurt-am-Main, 20-37

Müller-Starck G, Ziehe M (1991) Genetic variation in populations of Fagus sylvatica L, Quercus robur L and Quercus petraea Libl in Germany. In: Genetic Variation in European Populations of Forest Trees (Müller-Starck G, Ziehe M, eds), Sauerländer's Verlag, Frankfurt-am-Main, 125-140

Müller-Starck G, Herzog S, Hattemer HH (1993) Intraand interpopulational genetic variation in juvenile populations of Quercus robur L and Quercus petraea Liebl. Ann Sci For 50, 233s-244s

Nei M (1973) Analysis of gene diversity in subdivided populations. Proc Natl Acad Sci USA 70, 3321-3323

Zanetto A, Roussel G, Kremer A (1994) Geographic variation of inter-specific differentiation between Quercus robur $\mathrm{L}$ and Quercus petraea (Matt) Liebl. For Genet 1, 111-123

Ziehe M, Gregorius HR, Glock H, Hattemer $\mathrm{HH}$, Herzog $S$ (1989) Gene resources and gene conservation in forest trees: general concepts. In: Genetic Effects of Air Pollutants in Forest Tree Populations (Scholz F, Gregorius HR, Rudin D, eds), Springer-Verlag, Berlin, 173-185 